\title{
Allocation of the ICU wards according to the patient's infection condition: a measure to improve antibiotic resistance
}

\author{
Yefei Zhan ${ }^{1,2 \dagger}$, Peifu Chen ${ }^{1,2 \dagger}$, Jieqiong Chen ${ }^{1,2}$, Hua Wang ${ }^{1,2}$, Zhaojun $X u^{1,2^{*}}$ (ID) and Yu Chen ${ }^{1,2^{*}}$
}

Keywords: Intensive care unit, Nosocomial infections, Multidrug-resistant organism, Environmental contamination, Isolation precaution

Pathogens are known to survive on surfaces in health care environments despite routine cleaning and nearly always cause nosocomial infections [1-3]. The number of health care-associated infections is progressively increasing and the extent of multidrug-resistant organisms (MDROs) in medical institutions is of worldwide concern and continues to challenge infection control $[4,5]$. The aim of our study was to find the simplest and most effective way to reduce the spread of MDROs by using "infection grade ward isolation" (IGWI).

We conducted a 1-year prospective study to evaluate the impact of the IGWI method on MDRO environmental contamination and colonization in the intensive care unit (ICU). The study comprised a 3-month baseline period and a 9-month intervention period. The baseline period ranged from March 1, 2018, to May 31, 2018. There was no difference between ICU-1 (10 single rooms and 5 double rooms with 20 beds) and ICU-2 (newly built, 2 multi-bed rooms with 12 beds) in terms of patient admission, medication, and ward disinfection. The intervention period lasted from June 1, 2018, to February 28, 2019. During this period, IGWI was implemented; patients with MDRO infections or who used more than a third-generation cephalosporins or other

\footnotetext{
*Correspondence: zhaojunxu168@163.com; 283304036@qq.com

${ }^{\dagger}$ Yefei Zhan and Peifu Chen contributed equally to this work and should be considered co-first authors.

'Department of Intensive Care Unit, Hwa Mei Hospital, University of Chinese Academy of Sciences, No.41, Northwest Street, Ningbo 315010, Zhejiang, China

Full list of author information is available at the end of the article
}

strong antibiotics were not allowed into ICU-2, and patients in ICU-2 needing advanced antibiotics or with newly found MDROs were quickly transferred to ICU-1. Both wards had noninterchangeable equipment, work clothes, and noninteracting staff.

Samples from five different surfaces-an air conditioning vent, an oxygenation probe, an intravenous pump, a bed rail button, and a sheet (from around the perineal area of the patient) - from 32 beds ( 20 beds in ICU-1 and 12 beds in ICU-2) were collected on sterile rayon swabs each month, which were then cultured for the presence of MDROs.

We collected 1920 swabs over 1 year-1200 from ICU-1 and 720 from ICU-2-480 were collected during the baseline period and 1440 during the intervention period. Of these 1920 swabs, 73 were MDRO positive (Table 1). During the baseline period, the MDRO detection rate was 6.7 $\sim 10.0 \%$ (Table 2), and there was no difference in the incidence of MDROs (6.7 vs. $10.0 \%, P=0.109$, Table 2) between ICU-2 and ICU-1. During the intervention period using the IGWI method, the MDRO overall detection rate in for both ICU wards was reduced to $0 \sim 3.4 \%$ (Table 2). The positive rate of MDROs in the sample cultures was greater in ICU-1 than in ICU-2 (3.4 vs. $0 \%, P=0.007$ ). Both wards had a greater proportion of positive results for MDROs during the baseline stage than after the intervention (ICU-1 10 vs. 3.4\%, respectively, $P<0.001$; ICU-2 6.7 vs. $0 \%$, respectively, $P<0.001$; Table 2 ).

We found a very effective technique-the IGWI method-that in essence helps prevent non-MDRO- 


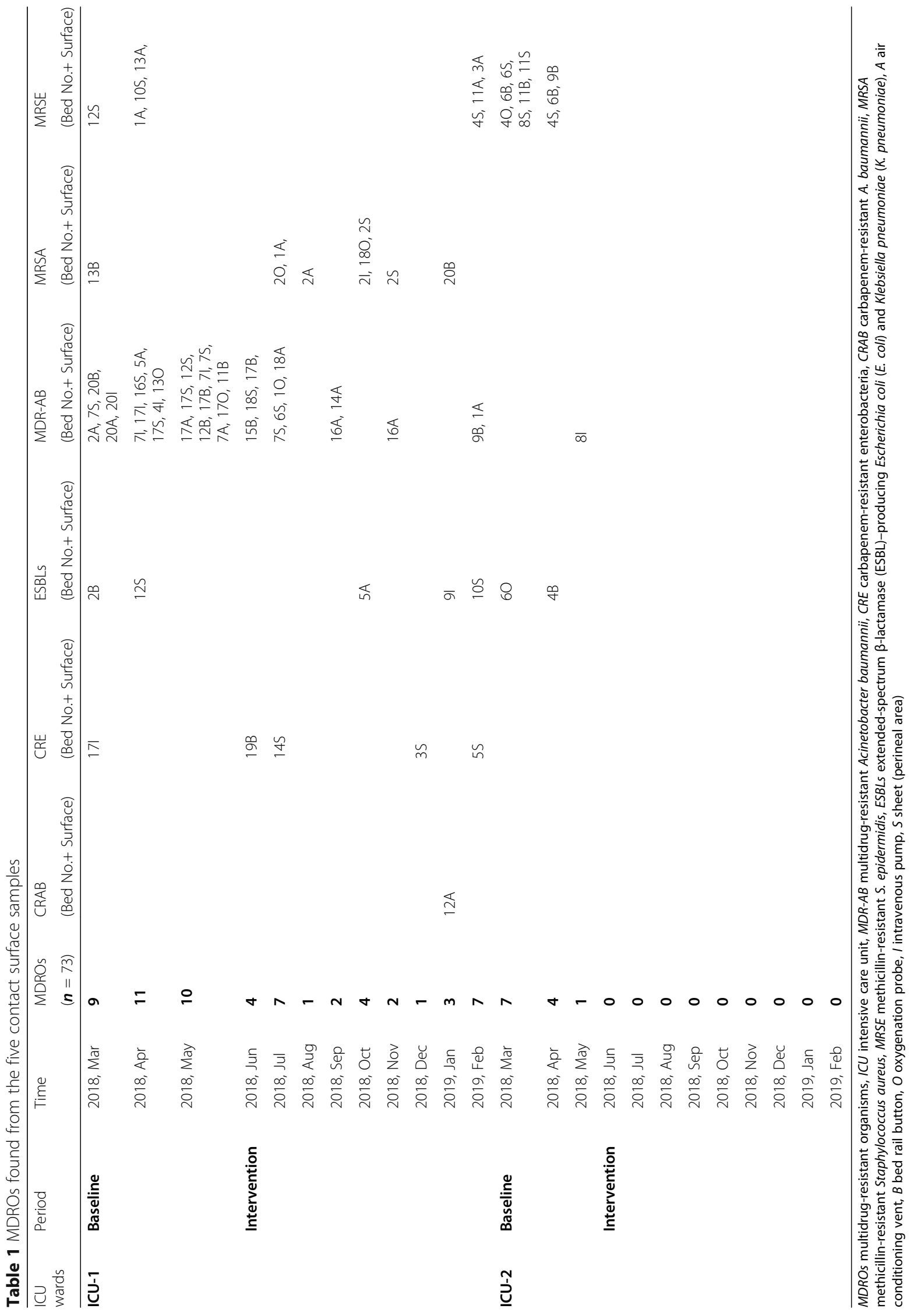


Table 2 Positive cultures of MDROs from samples taken from contact surfaces during the 1-year study

\begin{tabular}{|c|c|c|c|}
\hline \multirow[t]{2}{*}{ Time } & \multicolumn{2}{|l|}{ MDROs [n (\%)] } & \multirow[t]{2}{*}{$\boldsymbol{P}$ value } \\
\hline & $\begin{array}{l}\text { ICU-1 } \\
{[\mathrm{n} / \mathrm{N}(\mathrm{n} \%), N=100]}\end{array}$ & $\begin{array}{l}\text { ICU-2 } \\
{[\mathrm{n} / \mathrm{N}(\mathrm{n} \%), N=60]}\end{array}$ & \\
\hline Baseline & $30 / 300(10.0 \%)$ & $12 / 180(6.7 \%)$ & 0.109 \\
\hline 2018, Mar & 9/100 (9.0\%) & $7 / 60$ (11.7\%) & \\
\hline 2018, Apr & $11 / 100$ (11.0\%) & $4 / 60(6.7 \%)$ & \\
\hline 2018, May & $10 / 100$ (10.0\%) & $1 / 60(1.7 \%)$ & \\
\hline Intervention & $31 / 900$ (3.4\%) & $0 / 540(0.0 \%)$ & 0.007 \\
\hline 2018, Jun & 4/100 (4.0\%) & 0/60 (0.0\%) & \\
\hline 2018, Jul & 7/100 (7.0\%) & 0/60 (0.0\%) & \\
\hline 2018, Aug & 1/100 (1.0\%) & 0/60 (0.0\%) & \\
\hline 2018, Sep & 2/100 (2.0\%) & 0/60 (0.0\%) & \\
\hline 2018, Oct & 4/100 (4.0\%) & 0/60 (0.0\%) & \\
\hline 2018, Nov & 2/100 (2.0\%) & 0/60 (0.0\%) & \\
\hline 2018, Dec & 1/100 (1.0\%) & 0/60 (0.0\%) & \\
\hline 2019, Jan & 3/100 (3.0\%) & 0/60 (0.0\%) & \\
\hline 2019, Feb & 7/100 (7.0\%) & 0/60 (0.0\%) & \\
\hline$P$ value & $<0.001$ & $<0.001$ & \\
\hline
\end{tabular}

ICU intensive care unit, MDROs multidrug-resistant organisms

infected patients who enter the ICU from coming into contact with MDRO environment. The IGWI method has two criteria for distinguishing ICU patientswhether the patients are infected by MDROs or are using or in need of advanced antibiotics.

Currently, ICU departments are always divided into different wards to receive patients with different diseases. Many patients who are not infected with drugresistant bacteria could be exposed to a bad ICU environment and become innocent victims of environmental contamination. For quarantined patients, the unconscious negligence of a person or a link often results in quarantine failure [6] and risks drug-resistant bacterial infection of those patients with nonresistant bacterial infections [3]. This study found that breaking the traditional protocol and using the IGWI method to differentiate patients in different ICU wards would greatly reduce the environmental MDRO infection rate.

\section{Abbreviations}

MDROs: Multidrug-resistant organisms; IGWI: Infection grade ward isolation; ICU: Intensive care unit

\section{Acknowledgements}

Not applicable

\section{Authors' contributions}

YF Z and PF C conducted the statistical analyses and edited the initial draft of the manuscript. JQ C and HW participated in data collection. ZJ X and Y $C$ conceptualized and designed the study. All authors read and approved the final manuscript.

\section{Funding}

This research was supported by Zhejiang Provincial Natural Science Foundation of China (Grant No.LY19H190001); Ningbo Medical Key Discipline, China (Grant No.2016-B04); Medical Scientific Research Foundation of Zhejiang Province, China (Grant No.2018KY688); and Ningbo Natural Science Foundation, China (Grant No.2018A610247).

\section{Availability of data and materials}

All collected data were listed in an anonymous database. The dataset is not available but can be requested from the corresponding author.

Ethics approval and consent to participate

Not applicable

\section{Consent for publication}

Not applicable

Competing interests

The authors declare that they have no competing interests.

\section{Author details}

'Department of Intensive Care Unit, Hwa Mei Hospital, University of Chinese Academy of Sciences, No.41, Northwest Street, Ningbo 315010, Zhejiang, China. ${ }^{2}$ Ningbo Institute of Life and Health Industry, University of Chinese Academy of Sciences, Ningbo, China.

Received: 22 May 2020 Accepted: 20 July 2020

Published online: 29 July 2020

References

1. Magill SS, Edwards JR, Bamberg W, Beldavs ZG, Dumyati G, Kainer MA, Lynfield R, Maloney M, McAllister L, Nadle J, et al. Multistate pointprevalence survey of health care-associated infections. New Engl J Med. 2014;370(13):1198-208.

2. Bengtsson J, Kristiansson E, Larsson DG. Environmental factors influencing the development and spread of antibiotic resistance. FEMS Microbiol Rev. 2018:42(1):fux053.

3. Sued BP, Pereira PM, Faria YV, Ramos JN, Binatti VB, Santos KR, Seabra SH, Júnior RH, Vieira W, Mattos AL, et al. Sphygmomanometers and thermometers as potential fomites of staphylococcus haemolyticus: biofilm formation in the presence of antibiotics. Mem I Oswaldo Cruz. 2017;112(3): 188-95.

4. Ferri M, Ranucci E, Romagnoli P, Giaccone V. Antimicrobial resistance: a global emerging threat to public health systems. Crit Rev in Food Sci. 2017; 57(13):2857-76.

5. Sib E, Voigt AM, Wilbring G, Schreiber C, Faerber HA, Skutlarek D, Parcina M, Mahn $R$, Wolf $D$, Brossart $P$, et al. Antibiotic resistant bacteria and resistance genes in biofilms in clinical wastewater networks. Int J Hyg Environ Health. 2019;222(4):655-62.

6. Dunn AN, Donskey CJ, Gordon SM, Deshpande A. Multidrug-resistant organisms on patients hands in an ICU setting. Infect Control Hosp Epidemiol. 2020;41(2):239-40.

\section{Publisher's Note}

Springer Nature remains neutral with regard to jurisdictional claims in published maps and institutional affiliations.
Ready to submit your research? Choose BMC and benefit from:
- fast, convenient online submission
- thorough peer review by experienced researchers in your field
- rapid publication on acceptance
- support for research data, including large and complex data types
- gold Open Access which fosters wider collaboration and increased citations
- maximum visibility for your research: over $100 \mathrm{M}$ website views per year
At $\mathrm{BMC}$, research is always in progress.
Learn more biomedcentral.com/submissions 